\title{
Fluctuation in the Functional Activity of Human Colostrum Phagocytes to Streptococcus pneumoniae and Enteropathogenic Escherichia coli
}

Eduardo Luzía França ${ }^{1,2}$, Cristiane Castro Pernet Hara ${ }^{2}$, Danny Laura Gomes Fagundes ${ }^{2}$, Nayara Aires Peixoto Lima ${ }^{3}$, Silvia Hanna Bilotti Ratto $^{3}$, Adenilda Cristina Honorio-Franca ${ }^{1,2 *}$

${ }^{1}$ PostGraduate Program in Immunology and Parasitology, Institute of Biological and Health Sciences, Federal University of Mato Grosso, Barra do Garça, MT ${ }^{2}$ PostGraduate Program in Material Science, Institute of Biological and Health Sciences, Federal University of Mato Grosso, Barra do Garças, MT ${ }^{3}$ Institute of Biological and Health Science, Federal University of Mato Grosso, Pontal do Araguaia, MT, Brazil

\begin{abstract}
Colostrum was shown to protect children against gastrointestinal and respiratory infections and to exhibit chronobiological variations in cellular and soluble components. However, circadian variations in the activity of these colostral elements are only partially understood. This study compared colostrum samples collected in the diurnal and nocturnal periods by assessing phagocytic activity against enteropathogenic Escherichia coli (EPEC) and Streptococcus pneumoniae (S. pneumoniae) as well as the role of colostral cells and soluble elements. Colostrum samples were collected from 30 mothers during both day and night. Superoxide anion release, phagocytosis and bactericidal activity by colostral mononuclear $(\mathrm{MN})$ and polymorphonuclear (PMN) phagocytes in the presence of EPEC or S. pneumoniae were determined. Colostrum samples collected in the diurnal period had higher superoxide release in opsonized than in non-opsonized EPEC and S. pneumoniae, whereas in nocturnal samples it was increased in PMN phagocytes incubated with serum-opsonized S. pneumoniae. MN and PMN phagocytes in colostrum collected in both periods exhibited phagocytic activity for the bacteria tested. The highest EPEC killing by MN phagocytes was observed in samples collected in the diurnal period. The bactericidal activity of PMN phagocytes against EPEC was higher when bacteria were opsonized and in samples collected in the diurnal period For opsonized S. pneumoniae, phagocytes had similar bactericidal activity, irrespective of colostrum collection period. These data support the hypothesis that there is a fluctuation in the functional activity of colostral phagocytes, which is dependent on synchronization among feeding time, pathogen features and infection area.
\end{abstract}

Keywords: Bacteria, Colostrum, Infections, Phagocytes, Opsonin

\section{Introduction}

Protective factors in colostrum and breast milk combat pathogens in children [1-5]. Colostrum in particular is a rich source of nutrients and the host of immunological components that play an important role in infant protection against gastrointestinal and respiratory infections [3] commonly associated to specific pathogens. This is true for acute diarrhea, the second main cause of death in infants of low socioeconomic status in developing countries [6]. During their first year of life, the main etiological agent of diarrhea in infants is enteropathogenic Escherichia coli (EPEC) [7,8]. EPEC is also a major causative agent of death from diarrhea in children under five years of age [9]. Another important pathogen that attacks infants is the bacterium Streptococcus pneumoniae. Mostly associated with acute otitis media and S. pneumoniae is the second most common cause of meningitis in children under 2 years of age [10].

Colostrum and breast milk, which are known to play an antiinfection, protective role against pathogens $[1,3,11]$, are particularly rich in secretory IgA (SIgA), which blocks bacterial adherence to human epithelial cells, neutralizes toxins and prevents viral infections [3]. IgA acts as an opsonin, thereby increasing free radical production, phagocytosis and microbicidal activity of colostral cells $[8,15,13]$ through interactions with the Fca receptor [1,11,12]. Colostrum contains antibodies that combat a variety of bacteria and has the capacity to inhibit the adhesion of different EPEC serotypes [7]. IgA contained in colostrum and breast milk has proven to be effective against a number of microorganisms [12].

In addition to antibodies, soluble bioactive components and antiinfectious factors, human colostrum contains large amounts of viable leukocytes $\left(1 \times 10^{9}\right.$ cells $/ \mathrm{mL}$ in the first days of lactation), especially macrophages and neutrophils [13]. These cells produce free radicals and have phagocytic and bactericidal activity [14,15]. In bacterial infections, phagocytes are known to be the main cell lineage in host defense [15].

Stimulatory signals released during SIgA interaction with its Fc receptor activates human colostral phagocytes [12,16,17], which exhibit phagocytic activity and produce oxygen-free radicals. The bactericidal activity of colostral mononuclear phagocytes after opsonization with SIgA is equivalent to that of mononuclear and polymorphonuclear phagocytes from peripheral blood $[1,11]$.

Colostrum may represent a complete micro-environment, in which both soluble and cellular components act together [1,3]. Given that colostrum is the secretion with the highest amount of SIgA, the biological activity and interactions of this antibody are of

*Corresponding author: AC Honorio-França, Instituto de Ciências Biológicas e da Saúde, UFMT, Pontal do Araguaia, MT, Rodovia BR070, Km 5 s/no, Barra do Garças, MT, Brazil, Tel: 55-6634021121; Fax: 55-6634021117 CEP: 78698-000; E-mail: denifran@terra.com.br

Received November 22, 2011; Accepted December 26, 2011; Published January 02, 2012

Citation: França EL, Pernet Hara CC, Gomes Fagundes DL, Peixoto Lima NA, Bilott Ratto SH, et al. (2012) Fluctuation in the Functional Activity of Human Colostrum Phagocytes to Streptococcus pneumoniae and Enteropathogenic Escherichia coli. J Medical Microbiol Diagnosis 1:104. doi:10.4172/2161-0703.1000104

Copyright: () 2012 França EL, et al. This is an open-access article distributed under the terms of the Creative Commons Attribution License, which permits unrestricted use, distribution, and reproduction in any medium, provided the original author and source are credited. 
Citation: França EL, Pernet Hara CC, Gomes Fagundes DL, Peixoto Lima NA, Bilotti Ratto SH, et al. (2012) Fluctuation in the Functional Activity of Human Colostrum Phagocytes to Streptococcus pneumoniae and Enteropathogenic Escherichia coli. J Medical Microbiol Diagnosis 1:104. doi:10.4172/2161-0703.1000104

Page 2 of 6

great importance, especially because they possibly play an important protective role against different pathogens in the gastrointestinal and respiratory tract of newborns [18]

Other studies show that the immunological components of colostrum exhibit a chronobiological profile, suggesting the existence of an auxiliary physiological mechanism for defense against infections in children, since there is a predominance of immune components in milk in the daytime, when the probability of exposure to infectious agents is higher [19].

To assess the circadian variations in the immunological potential of colostrum, the present study compared colostrum samples collected in the diurnal and nocturnal periods by assessing phagocyte activity against EPEC and S. pneumoniae as well as the role of colostral cells and soluble elements.

\section{Materials and Methods}

\section{Subjects}

After an informed consent form had been signed by the volunteers, about $15 \mathrm{~mL}$ of colostrum was collected from clinically healthy women, 18-35 years of age, at the Health System Program of Barra do Garças, Mato Grosso, Brazil $(\mathrm{N}=30)$. All the mothers had given birth to healthy term babies through vaginal delivery. Two colostrum samples were collected in sterile plastic tubes between 48 and 72 hours postatpartum at 12:00h (diurnal period) and 24:00 h (nocturnal period) from each mother, according to França et al. [19], with a total of 60 samples. All procedures were submitted for ethical evaluation and obtained Institutional approval.

\section{Obtaining supernatant from human colostrums}

Colostrum supernatant samples of different puerperae, collected manually in sterile plastic tubes in two periods of time was obtained by centrifugation $\left(10 \mathrm{~min}, 160 \times \mathrm{g}, 4^{\circ} \mathrm{C}\right)$, the upper fat layer was discarded, and the aqueous supernatant stored at $-70^{\circ} \mathrm{C}$ for posterior IgA separation e determination.

\section{Separation of colostral cells}

Colostrum samples were centrifuged $\left(160 \times \mathrm{g}, 4^{\circ} \mathrm{C}\right)$ for $10 \mathrm{~min}$. Centrifugation separated colostrum into three different phases: cell pellet, an intermediate aqueous phase, and a lipid-containing supernatant, as described by Honorio-França et al. [1]. Cells were separated by a Ficoll-Paque gradient (Pharmacia, Upsala, Sweden), producing preparations with $95 \%$ of pure polymorphonuclear cells and $98 \%$ of pure mononuclear cells, analyzed by light microscopy. Purified neutrophils and macrophages were resuspended independently in serum-free 199 medium at a final concentration of $2 \times 10^{6}$ cells $/ \mathrm{mL}$.

\section{Purified colostral SIgA}

Human SIgA was purified from a defatted colostrum pool by affinity chromatography on Cyanogen Bromide-Activated Sepharose4B (CNBr-Sepharose-4B - Sigma, ST Loius, USA) bound with sheep anti-human $\alpha$ chain as proposed by March et al. [20]. To ensure SIgA depletion, fractions eluted from the affinity chromatography column were pooled and passed five times through the same column. Bound SIgA was eluted from the column with $6 \mathrm{~N}$ glycine - HCL buffer, $\mathrm{pH}$ 2.8. The purified preparations were restored to the initial volume. The concentration of SIgA was determined by simple radial immunodiffusion with a sheep anti-human $\alpha$ chain serum on agarose plates. Protein total concentration was available by Lowry Method. The purified SIgA preparation was also tested by immunoelectrophoresis with goat anti-human $\gamma$ and $\mu$ chain antisera. Both IgG and IgM were undetectable in the preparation.

\section{IgA determination by quantitative radial immunodiffusion (RID)}

SIgA concentrations in colostrum groups were determined as proposed by Mancini et al. [21]. Antibody levels in human colostrum were determined with an anti-human IgA, lamb serum (Biolab) and the Kallestad standard curve. All the experiments were performed in duplicate and triplicate.

\section{E. coli strain}

The enterophatogenic Escherichia coli (EPEC) used was isolated from stools of an infant with acute diarrhea (serotype 0111:H2, LA1, eae1, EAF1, bfp1). This material was prepared and adjusted to $10^{7}$ bacteria/ml, as previously described [1]

\section{Streptococcus pneumoniae strain}

The Streptococcus pneumoniae ATCC ${ }^{\circledR} 6305$ was used (obtained from American Type Culture Collection, ATCC). This material was prepared and adjusted to $10^{7}$ bacteria/ml, as previously described [1].

\section{Bacterial opsonization}

EPEC or S. pneumoniae were opsonized as described by BellinatiPires et al. [22]. Three opsonins were used:

Colostrum supernatant: A pool of 10 colostral samples (immunoglobulin concentration $\mathrm{g} / \mathrm{L}: \mathrm{IgA}=7.4$; $\operatorname{IgG}=0.15$ and $\mathrm{IgM}$ $=0.37$ ) was defatted by repeated centrifugation at $160 \times \mathrm{g}$ for $10 \mathrm{~min}$ at $4^{\circ} \mathrm{C}$. The aliquots were stocked at $-80^{\circ} \mathrm{C}$ and subsequently used for bacteria opsonization.

Purified colostral SIgA: Purified colostral IgA as described above. The purified SIgA was $4.0 \mathrm{~g} / \mathrm{L}$ adjusted to a concentration of $0.74 \mathrm{~g} / \mathrm{L}$ (to be used in a proportion equivalent to $10 \%$ of the SIgA contained in the standard colostrum sample). The aliquots were stocked at $-80^{\circ} \mathrm{C}$ and subsequently used for bacteria opsonization

Sera: A pool of normal human serum samples from 10 volunteer donors (immunoglobulin concentration $\mathrm{g} / \mathrm{L}$ : $\operatorname{IgA}=2.64 ; \mathrm{IgG}=14.0$ and $\operatorname{IgM}=2.0$ ) was prepared, the aliquots stocked at $-80^{\circ} \mathrm{C}$ for subsequent bacteria opsonization.

Colostrum supernatant, serum and purified IgA were thawed and mixed with appropriate volumes of bacterial suspension to a final concentration of $2 \times 10^{7}$ bacteria/mL in $10 \%$ of the opsonin sources. Other bacterial suspension prepared at the same concentration in 199 medium without opsonin was used as an untreated bacterial control. Both bacterial suspensions were incubated for $30 \mathrm{~min}$ at $37^{\circ} \mathrm{C}$ and used in the superoxide release and bactericidal assays.

\section{Release of superoxide anion}

Superoxide release was determined by cytochrome C (Sigma, ST Loius, USA) reduction [1,23]. Briefly, mononuclear phagocytes and bacteria were mixed and incubated for $30 \mathrm{~min}$ for phagocytosis. Cells were then resuspended in Phosphate Buffer Solution (PBS) containing $2.6 \mathrm{mM} \mathrm{CaCl}_{2}, 2 \mathrm{mM} \mathrm{MgCl}_{2}$, and cytochrome C (Sigma, ST Loius, USA 
Citation: França EL, Pernet Hara CC, Gomes Fagundes DL, Peixoto Lima NA, Bilotti Ratto SH, et al. (2012) Fluctuation in the Functional Activity of Human Colostrum Phagocytes to Streptococcus pneumoniae and Enteropathogenic Escherichia coli. J Medical Microbiol Diagnosis 1:104. doi:10.4172/2161-0703.1000104

$2 \mathrm{mg} / \mathrm{mL})$. The suspensions $(100 \mu \mathrm{L})$ were incubated for $60 \mathrm{~min}$ at $37^{\circ} \mathrm{C}$ on culture plates. The reaction rates were measured by absorbance at $550 \mathrm{~nm}$ and the results were expressed as $\mathrm{nmol} / \mathrm{O}^{2-}$. All the experiments were performed in duplicate or triplicate.

\section{Bactericidal assay}

Phagocytosis and Microbicidal activity were evaluated by the acridine orange method described by Bellinati-Pires et al. [22]. Equal volumes of bacteria and cell suspensions were mixed and incubated at $37^{\circ} \mathrm{C}$ for $30 \mathrm{~min}$ under continuous shaking. Phagocytosis was stopped by incubation in ice. To eliminate extracellular bacteria, the suspensions were centrifuged twice $\left(160 \times \mathrm{g}, 10 \mathrm{~min}, 4^{\circ} \mathrm{C}\right)$. Cells were resuspended in serum-free 199 medium and centrifuged. The supernatant was discarded and the sediment dyed with $200 \mu \mathrm{L}$ of acridine orange (Sigma, ST Loius, USA; $14.4 \mathrm{~g} / \mathrm{L}$ ) for $1 \mathrm{~min}$. The sediment was resuspended in cold culture 199 medium, washed twice and observed under immunofluorescence microscope at 400X and 1000X magnification. The phagocytosis index was calculated by counting the number of cells ingesting at least 3 bacteria in a pool of 100 cells. To determine the bactericidal index, we stained the slides with acridine orange and counted 100 cells with phagocytized bacteria. The bactericidal index is calculated as the ratio between orange- stained [dead] and greenstained [alive] bacteria $\times 100$ [22]. All the experiments were performed in duplicate or triplicate.

\section{Statistical analysis}

Analysis of variance (ANOVA) was used to evaluate superoxide anion release, phagocytosis and bactericidal index in the presence or absence of opsonized bacteria. Statistical significance was considered for a $\mathrm{p}$-value lower than $0.05(\mathrm{p}<0.05)$.

\section{Results}

\section{Superoxide release by colostral phagocytes in the presence of EPEC and S. pneumoniae}

PMN and MN phagocytes exposed to non-opsonized EPEC had spontaneous superoxide release in diurnal collection (Figure $1 \&$ Figure 2). MN phagocytes increased superoxide anion release in the presence of S. pneumonia opsonized with colostrum and EPEC opsonized with $\operatorname{IgA}$, irrespective of colostrum collection period. In samples collected in the diurnal period, superoxide release was higher in bacteria opsonized with serum than in non-opsonized EPEC and S. pneumoniae. The superoxide release by MN phagocytes was higher in presence of EPEC opsonized than S. pneumonia opsonized with IgA (Figure 1). In both periods, superoxide release was higher between PMN phagocytes incubated with EPEC, regardless of the type of opsonin used. In diurnal period, opsonized S. pneumoniae had higher superoxide release by PMN phagocytes (Figure 2).

\section{Phagocytic activity of colostral MN and PMN cells against EPEC and S. pneumoniae}

MN and PMN phagocytes in colostrum samples collected in both the diurnal and nocturnal period exhibited phagocytic activity for both bacteria tested. The highest phagocytosis index was observed in $\mathrm{MN}$ and PMN phagocytes incubated with S. pneumoniae, irrespective of the colostrum collection period. In diurnal colostrum samples, phagocytosis was higher when EPEC was opsonized. All types of opsonin induced equivalent phagocytosis rates by colostral MN and

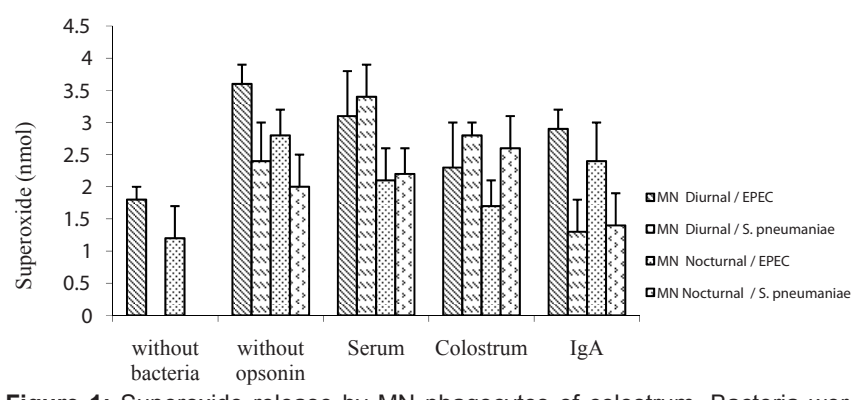

Figure 1: Superoxide release by MN phagocytes of colostrum. Bacteria were opsonized with a normal serum pool (Serum), a colostrum supernatant pool (colostrum) and purified $\lg \mathrm{A}(\lg \mathrm{A})$. In control assays, MN cells were pre-incubated with bacteria non-opsonized. The results represent the mean and SD of ten experiments with cells from different individuals. ${ }^{*} p=0.001(F=5.11)$ comparing the treated groups with spontaneous superoxide released, considering the same collection period and bacteria. ${ }^{p}=0.001 \quad(F=10.92)$ comparing bacteria type, considering the same opsonin source and collection time. ${ }^{\dagger} p=0.048(F=2.68)$ comparing superoxide release between the different collection time, considering the same treatment and bacteria.

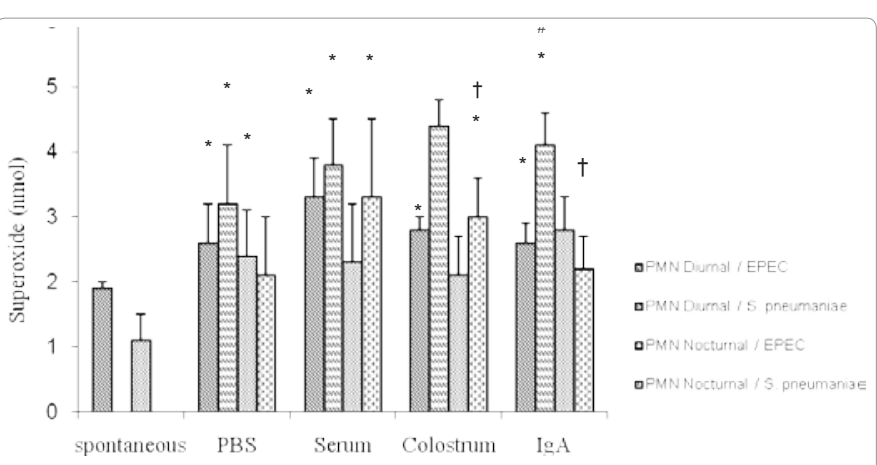

Figure 2: Superoxide release by $\mathrm{PMN}$ phagocytes of colostrum. Bacteria were opsonized with a normal serum pool (Serum), a colostrum supernatant pool (colostrum) and purified IgA (IgA). In control assays, PMN cells were preincubated with bacteria non-opsonized. The results represent the mean and $\mathrm{SD}$ of ten experiments with cells from different individuals. ${ }^{*} \mathrm{p}=0.001(\mathrm{~F}=18.96)$ comparing the treated groups with spontaneous superoxide released, considering the same collection period and bacteria. ${ }^{*} \mathrm{p}=0.001(\mathrm{~F}=20.3)$ comparing bacteria type, considering the same opsonin source and collection time. ${ }^{\dagger} p=0.003$ $(\mathrm{F}=2.83)$ comparing superoxide release between the different collection time, considering the same treatment and bacteria.

PMN (Table 1). In both diurnal and nocturnal colostrum samples, the phagocytosis index did not change when $\mathrm{MN}$ or PMN phagocytes were incubated with opsonized S. pneumoniae. In samples collected in the nocturnal period, the phagocytosis index in MN cells was higher only when incubated with serum-opsonized EPEC (Table 1).

\section{Elimination of EPEC and S. pneumoniae by Colostral MN and PMN Phagocytes}

Colostral MN and PMN phagocytes had a higher bactericidal activity against $S$. pneumoniae than EPEC in both diurnal and nocturnal colostrum samples. The bacterial activity of colostral MN, regardless of the collection period, was higher against EPEC when it was opsonized with the different opsonins. The highest EPEC killing by MN phagocytes was observed in samples collected in the diurnal period (Table 2). The bactericidal activity of PMN phagocytes against EPEC was higher when the bacteria were opsonized and in samples collected in the diurnal period (Table 2). For opsonized S. pneumoniae, 
Citation: França EL, Pernet Hara CC, Gomes Fagundes DL, Peixoto Lima NA, Bilotti Ratto SH, et al. (2012) Fluctuation in the Functional Activity of Human Colostrum Phagocytes to Streptococcus pneumoniae and Enteropathogenic Escherichia coli. J Medical Microbiol Diagnosis 1:104. doi:10.4172/2161-0703.1000104

Page 4 of 6

\begin{tabular}{|c|c|c|c|c|c|}
\hline \multirow{3}{*}{ Bacteria treatment } & \multirow{3}{*}{ Phagocytes } & \multicolumn{4}{|c|}{ Phagocytosis index (\%) } \\
\hline & & \multicolumn{2}{|c|}{ Diurnal } & \multicolumn{2}{|c|}{ Nocturnal } \\
\hline & & EPEC & S. pneumoniae & EPEC & S. pneumonia \\
\hline PBS & $\begin{array}{l}\text { MN } \\
\text { PMN }\end{array}$ & $\begin{array}{l}49.1 \pm 6.9 \\
42.7 \pm 6.9\end{array}$ & $\begin{array}{c}71.5 \pm 6.1^{\#} \\
78.5 \pm 11.8^{\#}\end{array}$ & $\begin{array}{l}48.7 \pm 4.5 \\
45.2 \pm 5.4\end{array}$ & $\begin{array}{l}67.8 \pm 10.3^{\#} \\
75.3 \pm 13.6^{\#}\end{array}$ \\
\hline Serum & $\begin{array}{l}\text { MN } \\
\text { PMN }\end{array}$ & $\begin{array}{l}60.0 \pm 6.7^{*} \\
59.2 \pm 8.8^{*}\end{array}$ & $\begin{array}{l}73.2 \pm 7.8 \\
79.0 \pm 13\end{array}$ & $\begin{array}{l}62.3 \pm 6.3^{*} \\
52.4 \pm 7.0\end{array}$ & $\begin{array}{l}63.2 \pm 7.5 \\
76.8 \pm 7.8^{\#}\end{array}$ \\
\hline Colostrum & $\begin{array}{l}\text { MN } \\
\text { PMN }\end{array}$ & $\begin{array}{l}62.0 \pm 5.8^{*} \\
58.0 \pm 13.9\end{array}$ & $\begin{array}{l}73.3 \pm 5.1 \\
78.4 \pm 7.6^{\#}\end{array}$ & $\begin{array}{c}58.4 \pm 7.8^{*} \\
52,3 \pm 8.9\end{array}$ & $\begin{array}{c}70.0 \pm 5.9 \\
70.5 \pm 7.0^{\#}\end{array}$ \\
\hline Purified SIgA & $\begin{array}{l}\text { MN } \\
\text { PMN }\end{array}$ & $\begin{array}{l}58.0 \pm 4.7^{*} \\
61.2 \pm 10.6\end{array}$ & $\begin{array}{l}75.2 \pm 7.2^{\#} \\
81.4 \pm 4.2^{\#}\end{array}$ & $\begin{array}{l}56.6 \pm 6.9 \\
52.1 \pm 6.4\end{array}$ & $\begin{array}{l}71.0 \pm 2.6^{\#} \\
76.2 \pm 9.5^{\#}\end{array}$ \\
\hline
\end{tabular}

Bacterial phagocytosis by colostrum phagocytes was determined with the acridine orange method. Bacteria were opsonized with a normal serum pool, a colostrum supernatant pool or purified SIgA. In controls assays, mononuclear (MN) and polimorphonuclear (PMN) cells were pre-incubated with PBS. * $\mathrm{p}=0.003(\mathrm{~F}=5.2)$ comparing the treated groups to PBS group, considering the same collection period, kind of cells and bacteria. ${ }^{*} \mathrm{p}=0.001$ ( $\left.\mathrm{F}=14.51\right)$ comparing bacteria type, considering the same opsonin source, kind of cells and collection time. $p=0.39(F=1.1)$ comparing phagocytosis between the different collection time, considering the same treatment, kind of cells and bacteria.

Table 1: Bacterial phagocytosis by colostral cells (mean $\pm \mathrm{SD}, \mathrm{N}=10$ in each treatment)

\begin{tabular}{|c|c|c|c|c|c|}
\hline \multirow{3}{*}{ Bacteria treatment } & \multirow{3}{*}{ Phagocytes } & \multicolumn{4}{|c|}{ Bactericidal index (\%) } \\
\hline & & \multicolumn{2}{|c|}{ Diurnal } & \multicolumn{2}{|c|}{ Nocturnal } \\
\hline & & EPEC & S. pneumoniae & EPEC & S. pneumonia \\
\hline PBS & $\begin{array}{l}\text { MN } \\
\text { PMN }\end{array}$ & $\begin{array}{l}25.7 \pm 4.2 \\
25.8 \pm 4.2\end{array}$ & $\begin{array}{l}58.6 \pm 10.5^{\#} \\
58.7 \pm 13.6^{\#}\end{array}$ & $\begin{array}{l}34.2 \pm 6.5 \\
21.1 \pm 4.8\end{array}$ & $\begin{array}{l}46.5 \pm 10.5 \\
59.3 \pm 5.5^{\#}\end{array}$ \\
\hline Serum & $\begin{array}{l}\text { MN } \\
\text { PMN }\end{array}$ & $\begin{array}{l}53.7 \pm 4.2^{*} \\
41.8 \pm 8.9^{*}\end{array}$ & $\begin{array}{l}56.2 \pm 12.3 \\
60.2 \pm 10.6\end{array}$ & $\begin{array}{c}58.7 \pm 5.6^{*} \\
32.4 \pm 7.5\end{array}$ & $\begin{array}{c}60.0 \pm 16.1^{*} \\
48.2 \pm 10.7\end{array}$ \\
\hline Colostrum & $\begin{array}{l}\text { MN } \\
\text { PMN }\end{array}$ & $\begin{array}{l}54.9 \pm 6.9^{*} \\
47.1 \pm 9.4^{*}\end{array}$ & $\begin{array}{l}51.7 \pm 14.2 \\
56.0 \pm 12.9\end{array}$ & $\begin{array}{l}44.4 \pm 3.8^{*} \\
32.3 \pm 5.0^{\dagger}\end{array}$ & $\begin{array}{c}62.7 \pm 8.2^{*} \\
62.5 \pm 11.0^{\#}\end{array}$ \\
\hline Purifed SIgA & $\begin{array}{l}\text { MN } \\
\text { PMN }\end{array}$ & $\begin{array}{l}53.5 \pm 8.1^{*} \\
43.8 \pm 5.4^{*}\end{array}$ & $\begin{array}{l}45.3 \pm 16.9 \\
55.4 \pm 17.5\end{array}$ & $\begin{array}{l}47.7 \pm 5.6^{*} \\
32.1 \pm 6.5^{\dagger}\end{array}$ & $\begin{array}{c}50.0 \pm 13.0 \\
49.0 \pm 6.3\end{array}$ \\
\hline
\end{tabular}

Bactericidal activity by colostrum phagocytes was determined with the acridine orange method. Bacteria were opsonized with a colostrum supernatant pool, purifeid SIgA or a normal serum pool. In controls assays, mononuclear (MN) and polimorphonuclear (PMN) cells were pre-incubated with PBS. The results represent the mean and SD of ten experiments with cells from different individuals. ${ }^{*} \mathrm{p}=0.001(\mathrm{~F}=5.11)$ comparing the treated groups to PBS group, considering the same collection period, kind of cells and bacteria. ${ }^{*} p=0.001(F=10.92)$ comparing bacteria type, considering the same opsonin source, kind of cells and collection time. ${ }^{t} p=0.048(F=2.68)$ comparing bactericidal active between the different collection time, considering the same treatment, kind of cells and bacteria.

Table 2: Bacterial elimination index (mean $\pm \mathrm{SD}, \mathrm{N}=10$ in each treatment).

MN or PMN phagocytes had similar bactericidal activity irrespective of colostrum collection period (Table 2).

\section{Discussion}

The composition of colostrum is dynamic and influenced by intrinsic factors. The present study shows that colostral phagocyte activity and soluble components fluctuate as a function of time of day and pathogen type. The immunological properties of human colostrum are important for children and some component levels may vary over time and during the course of feeding. The literature reports that milk composition changes during lactogenesis and that these changes can be used as biochemical markers of the onset of milk secretion [24]. Even this secretion can be modified as a function of both time of day and milk maturation and this variation is important for mothers and milk bank services that collect and distribute human milk [19].

Human colostrum is composed of soluble and cellular immunoprotector elements that combat a variety of pathogenic microorganisms [25]. Breastfeeding is therefore the best defense against mucosal infection in infants, especially in developing countries. Studies show that breastfeeding decreases the incidence and severity of pneumonia, diarrhea and other infections [26]. The protection offered by breastfeeding depends not only on immunoglobulin levels or other immunoreactive proteins $[27,28]$, but also on the amount, time and type of milk consumed $[19,27]$. Breast milk is rich in phagocytes with microbicidal activity and protects newborns from gastrointestinal and respiratory infections $[3,19]$.
In the present study, superoxide release changed according to colostrum collection period, indicating that phagocyte activity has a circadian pattern of variation. In the tests performed using opsonized bacteria, superoxide release increased in phagocytes from diurnal colostrum samples but not in those from nocturnal samples. These results confirm the importance of superoxide anions for bacterial death $[1,11,12,17]$ and the circadian influence on them [19]. The increase in superoxide release affected phagocytic bactericidal activity.

The levels of the different phagocyte types vary throughout colostrum and breast milk maturation. For instance, superoxide release by PMN phagocytes in colostrum and mature milk is higher in the diurnal phase, whereas for MN phagocytes from mature milk it is higher in the nocturnal phase [19]. Furthermore, colostrum contains two populations of phagocytes with different capacity for superoxide release and phagocytic and microbicidal activities. MN phagocytes exhibit intense microbicidal activity in the presence of opsonins, while PMN phagocytes, independent of opsonization, have low microbicidal activity $[1,11,12]$. This decreased PMN activity is associated to differences in receptors and superoxide release [11].

The activation mechanisms of human colostral phagocytes may depend on stimulatory signals generated by complement proteins and antibodies in milk, especially IgA, CR and FcR $[1,17]$. The combined action of these factors mediates signals that lead to degranulation, production of oxygen radicals and phagocytosis [29].

In colostrum samples collected in the diurnal phase, opsonization 
Citation: França EL, Pernet Hara CC, Gomes Fagundes DL, Peixoto Lima NA, Bilotti Ratto SH, et al. (2012) Fluctuation in the Functional Activity of Human Colostrum Phagocytes to Streptococcus pneumoniae and Enteropathogenic Escherichia coli. J Medical Microbiol Diagnosis 1:104. doi:10.4172/2161-0703.1000104

Page 5 of 6

increased EPEC phagocytosis but not that of S. pneumoniae. In samples collected in the nocturnal period, we observed an increase in phagocytic activity by MN cells only when they were incubated with serum-opsonized EPEC. Therefore, the phagocytic activity of human colostral cells likely depends on the action of opsonins, time of day and type of pathogen.

Phagocytosis and microbicidal activity by both blood and colostral phagocytes, with substantial participation of active oxygen metabolites such as free radicals, have been considered an important defense mechanism to protect infants against several infections [11,12,30-33]. Studies have suggested that colostrum phagocytes remain viable in the intestinal mucosa for a period of four hours [34], and are able to induce microbicidal activity in newborns [35].

This study confirms previous literature findings showing that SIgA-opsonization in particular increases superoxide release along with the phagocytic bactericidal activity of colostral mononuclear phagocytes [11-12]. Opsonized EPEC was eliminated by mononuclear phagocytes, and similar to the present study, microbicidal activity was stimulated in the presence of SIgA or other immunomodulatory agents $[1,32]$. Complementing these findings, we observed that colostral phagocytes exhibit higher bactericidal activity against non-opsonized S. pneumoniae than against EPEC, irrespective of time of day, and that activity against EPEC is opsonin-dependent.

IgA is a molecule produced by B lymphocytes stimulated by polysaccharide antigens present in bacterial capsules and nearly $70 \%$ of the colostral phagocytes have surface-bound SIgA, a proportion that is much higher than that of blood phagocytes [17]. With regards to colostral phagocytes, we found that, independently of opsonin, this cells present against non-opsonized S. pneumonia. This binding is likely promoted by presence of surface-bound SIgA in the phagocytes, which reinforces the important role they play for the protective properties of colostrum.

Our results also show that EPEC killing was greater in the diurnal phase, whereas elimination of $S$. pneumoniae was not related to time of day. The response to pneumococcal infection may be associated to macrophage activity [36]. Proteins involved in macrophage apoptosis may therefore facilitate intracellular bacterial killing [37,38]. Recently the literature has reported that activation of the abundant macrophage lysosomal protease, cathepsin $\mathrm{D}$, regulates the macrophage proteome during killing of Streptococcus pneumoniae. The cathepsin D regulates multiple proteins controlling the mitochondrial pathway of macrophage apoptosis or competing death processes, facilitating intracellular bacterial killing [37].

The protective effect of breastfeeding against the respiratory infections has become more evident in recent years. In particular, plays an important role in secretory $\operatorname{IgA}$ an antibody resulting from the mother's response to prior exposure to infectious agents. It has the characteristic to survive in the membranes of the respiratory mucosa and be resistant to proteolytic digestion. In addition to preventing pathogens from attaching cells of the breastfed infant, it limits the harmful effects of inflammation [39].

The presence of specific antibodies and phagocytes against pathogenic bacteria to the respiratory tract, along with the observation lower incidence of infections among breastfed the breast [40].
Colostral phagocytes exhibit bactericidal activity against different bacteria through interactions with soluble factors in colostrum, and this effect likely follows a circadian rhythm. The activity of phagocytes described here corroborates other studies that demonstrate the importance of breastfeeding in combating respiratory and gastrointestinal infections $[1,11,12,17,19,41,42]$.

These data confirm that colostrum have an important role in infant protection against gastrointestinal and respiratory infections and support the hypothesis of a fluctuation in the activity of colostral phagocytes that is dependent on synchronization between feeding time, pathogen features and infection area.

\section{Acknowledgement}

This research received grants from Fundação de Amparo à Pesquisa de Mato Grosso (FAPEMAT No 735593/2008; No 453387/2009; № 299032/2010) and Conselho Nacional de Pesquisa (CNPq No 475826/2010-8; No 475739/2011-6).

The authors declare no conflict of interest and non-financial competing interests.

\section{References}

1. Honorio-França AC, Carvalho MP, Isaac L, Trabulsi LR, Carneiro-Sampaio MMS (1997) Colostral mononuclear phagocytes are able to kill enteropathogenic Escherichia coli opsonized with colostral IgA. Scand J Immunol 46: 59-66.

2. Newburg DS (2005) Innate immunity and human milk. J Nutr 135: 1308-1312.

3. Hanson LA (2007) Feeding and infant development breast-feeding and immune fuction. Proc Nutrit Soc 66: 384-396.

4. Bessler HC, de Oliveira IR, Giugliano LG (2006) Human milk glycoproteins inhibit the adherence of Salmonella typhimurium to HeLa cells. Microbio Immunol 50: 877-882.

5. França-Botelho AC, Honorio-França AC, França EL, Gomes MA, Costa-Cruz JM (2006) Phagocytosis of Giardia lamblia trophozoites by human colostral leukocytes. Acta Paediatr 95: 438-443.

6. Kosek M, Bern C, Guerrant RL (2003) The global burden of diarrhoeal disease as estimated from studies published between 1992 and 2000. Bull World Health Organ 81: 197-204

7. Cravioto A, Tello A, Villafán H, Ruiz J, del Vedovo S, et al. (1991) Inhibition of localized adhesion of enteropathogenic Escherichia coli to HEp-2 cells by immunoglobulin and oligosaccharide fractions of human colostrum and breast milk. J Infect Dis 163: 1247-1255.

8. Gomes TAT, Rassi V, MacDonald KL, Silva-Ramos SRT, Trabulsi LR, et al (1991) Enteropathogens associated with acute diarrheal disease in urban infant in Sao Paulo, Brazil. J. Infect Dis 164: 331-337.

9. Black RE (1993) Epidemiology of diarrhoeal disease: implications for control by vaccines. Vaccine 11: 100-106.

10. Hausdorff WP, Bryant J, Paradiso PR, Siber GR (2000) Which pneumococcal serogroups cause the most invasive disease: implications for conjugate vaccine formulation and use, Part I. Clin Infect Dis 30: 100-121.

11. França EL, Bitencourt RV, Fujimori M, Morais TC, Calderon IMP, et al. (2011) Human colostral phagocytes eliminate enterotoxigenic Eschechia coli opsonized by colostrums supernatant. J Microbiol Immunol Infect 44: 1-7.

12. Honorio-França AC, Launay P, Carneiro-Sampaio MMS, Monteiro RC (2001) Colostral neutrophils express Fc alpha receptors [CD89] lacking gamma chain association and mediate noninflammatory properties of secretory IgA. J Leukoc Biol 69: 289-296.

13. Islam N, Ahmed L, Khan NI, Huque S, Begun A, et al. (2006) Immune components (IgA, IgM, IgG immune cells) of colostrum of Bangladeshi mothers. Pediatr Int 48: 543-548.

14. Brandileone MC, de Andrade AL, Di Fabio JL, Guerra ML, Austrian R (2003) Appropriateness of a pneumococcal conjugate vaccine in Brazil: potential impact of age and clinical diagnosis, with emphasis on meningitis. J Infect Dis 187: $1206-1212$ 
Citation: França EL, Pernet Hara CC, Gomes Fagundes DL, Peixoto Lima NA, Bilotti Ratto SH, et al. (2012) Fluctuation in the Functional Activity of Human Colostrum Phagocytes to Streptococcus pneumoniae and Enteropathogenic Escherichia coli. J Medical Microbiol Diagnosis 1:104. doi:10.4172/2161-0703.1000104

Page 6 of 6

15. Bhaskaram P, Reddy V (1981) Bactericidal activity of human milk leukocytes Acta Paediatr Scand 70: 87-90

16. Tonetti MS, Imboden MA, Gerber L, Lang NP, Laissue J, et al. (1994) Localized Expression of mRNA for Phagocyte-Specific Chemotactic Cytokines in Human Periodontal Infections. Infect Immun 62: 4005-4014.

17. França EL, Morceli G, Fagundes DLG, Rugde MVC, Calderon IMP, et al. (2011) Secretory IgA- Fca Receptor interaction modulating phagocytosis and microbicidal activity by phagocytes in human colostrum of diabetics. APMIS 119: $710-719$.

18. Zarban A, Taheri F, Chahkandi T, Sharifzadeh G (2007) Pattern of total antioxidant capacity in human milk during the course of lactation. Iranian J Pediat 17: 34-40

19. França EL, Nicomedes TR, Calderon IMP, Honorio-França AC (2010). Timedependent alterations of soluble and cellular components in human milk, Biol Rhythm Res 41: 333-347.

20. March SC, Parini I, Cuatrecasos P (1974) A simplified method for cyanogen bromide activation of agarose for affinity chromatography. Anal Biochem 60: 149-152.

21. Mancini G, Carbonare AO, Heremans JF (1965) Immunochemical quantitation of antigens by simple radial immunodiffusion. Immunochemistry 2: 235-236.

22. Bellinati-Pires R, Salgado MM, Hypolito IP, Grumach AS, Carneiro-Sampaio MM (1995) Application of a fluorochrome-lysostaphin assay to the detection of phagocytic and bactericidal disturbances in human neutrophils and monocytes. J Investig Allergol Clin Immunol 5: 337-342.

23. Pick E, Mizel D (1981) Rapid microassays for the measurement of superoxide and hydrogen peroxide production by macrophages in culture using an automatic enzyme immunoassay reader. J Immunol Methods 46: 211-226.

24. Oliveira IR, Bessler HC, Bao SN, Lima RL, Giugliano RL (2007) Inhibition of Enterotoxicogenic Escherichia coli [ETEC] adhesion to CACO-2 cells by human milk and its immunoglobulin and non-immunoglobulin fractions. Braz J Microbiol 38: 86-92.

25. Ciardelli L, Garofoli F, Stronati M, Mazzucchelli I, Avanzini MA, et al. (2008) Human colostrum $T$ lymphocytes and their effector cytokines actively aid the development of the newborn immune system. Int $\mathrm{J}$ Immunopathol Pharmacol 21: 781-786.

26. Giugliani ER (2000) Breastfeeding in clinical pratice. J Pediatr (Rio J) 76 S238-S252.

27. Islam N, Ahmed L, Khan NI, Huque S, Begun A, et al. (2006) Immune components (IgA, IgM, IgG immune cells) of colostrum of Bangladeshi mothers. Pediatr Int 48: 543-548.

28. DeCherney AH, Nathan L (2007) Immunologic significance of human milk.
Current Diagnosis \& Treatment Obstetrics \& Gynecology. New York: McGrawHill, pp 461-467.

29. Law D (1994) Adhesion and its role in the virulence of enteropathogenic Escherichia coli. Clin Micrbiol Rev 7: 152-173.

30. Vidarsson G, van Der Pol WL, van Den Elsen JM, Vile H, Jansen M, et al (2001) Activity of human IgG and IgA subclasses in immune defense against Neisseria meningitidis serogroup B. J Immunol 166: 6250-6256.

31. Linden SK, Sutton P, Karlsson NG, Korolik V, McGuckin MA (2008) Mucins in the mucosal barrier to infection. Mucosal Immunol 1: 183-197.

32. França-Botelho AC, Franca JL, Franca EL, Honorio-França AC, Busatti HGNO et al. (2010) Relationship between oxidative stress production and virulence capacity of Entamoeba strains. J Parasitol 5: 139-147.

33. França-Botelho AC, França JL, Oliveira FM, Franca EL, Honorio-França AC, et al. (2011) Melatonin reduces the severity of experimental amoebiasis. Parasit Vect 4: 62-67.

34. Hugaes A, Brock JH, Parrott DM, Cockburn F (1988) The interaction of infant formula with macrophages: effect on phagocytic activity, relationship to expression of class II MHC antigen and survival of orally administered macrophages in the neonatal gut. Immunology 64: 213-218.

35. Riedel-Caspari G (1993) The influence of colostral leukocytes on the couse of an experimental Escherichia coli infection and serum antibodies in neonatal calves. Vet Immunol Immunopathol 35: 275-288.

36. Wines BD, Hogarth PM (2006) IgA receptors in health and disease. Tissue Antigens 68: 103-114.

37. Fabrizio K, Manix C, Tian H, van Rooijen N, Pirofski, L (2010). The efficacy of pneumococcal capsular polysaccharide-specific antibidies to serotype 3 Streptococcus pneumoniae requires macrophages. Vaccine 28: 7542-7550.

38. Bewley MA, Pham TK, Marriott HM, Noirel J, Chu HP, et al. (2011) Proteomic evaluation and validation of cathepsin $D$ regulated proteins in macrophages exposed to Streptococcus pneumonia. Mol Cell Proteomics 10: 1-14.

39. Passanha A, Cervato-Mancuso AM, Pinto-Silva MEM (2010) Protective elements of breast milk in the prevention of gastrointestinal and respiratory diseases. Rev Braz Crescimento Desenvolvimento Hum 20: 351-360.

40. Venâncio SI (2003) Difficulties to establish breastfeeding: the role of supporting procedures provided by maternities. J Pediatr (Rio J) 79: 1-2.

41. Morrow AL, Rangel JM (2004) Human milk protection against infectious diarrhea: Implications for prevention and clinical care. Semin Pediatr Infect Dis 15: 221-228.

42. Carneiro-Sampaio MMS, Da Silva ML, Carbonare SB, Palmeira P, Delneri MT, et al. (1996) Breast-Feeding protection against Enteropathogenic Escherichia coli. Rev Microbiol 27: 120-125. 